\title{
Four Cyclopoid Species (Copepoda: Cyclopidae) from Limestone Caves and Lava Tube in South Korea
}

\author{
Ji Min Lee', Won-Rok Kim², Yong-Gun Choi ${ }^{2}$ \\ and Cheon Young Chang ${ }^{3, *}$ \\ 'Institute of Basic Science, Daegu University, Gyeongsan 712-714, Korea \\ ${ }^{2}$ The Korean Institute of Biospeleology, Yeongwol 230-808, Korea \\ ${ }^{3}$ Department of Biological Science, Daegu University, Gyeongsan 712-714, Korea
}

\begin{abstract}
As a result of the faunistic study on the subterranean cyclopoid copepods, four species of three genera in the family Cyclopidae are reported from nine limestone caves and a lava tube in South Korea: Megacyclops magnus (Marsh, 1920), Acanthocyclops orientalis Borutzky, 1966, A. robustus (Sars, 1863) and Diacyclops suoensis Ito, 1956, all of them new to Korean fauna. This paper deals with the taxonomic accounts and illustrations of the four species with the redescription of A. orientalis. This is the first taxonomic study on the cave-dwelling cyclopoid copepods from Korea.
\end{abstract}

Key words: taxonomy, Copepoda, Cyclopoida, Cyclopidae, cave, subterranean, Korea

\section{INTRODUCTION}

Subterranean cyclopoid fauna in Korea has been poorly known so far. Since Kim and Chang (1991) described Acanthocyclops tokchokensis from wells at Deogjeogdo Island in the Yellow Sea, only a few species have been reported sporadically from wells or springs. Lee et al. (2004) recorded two semi-subterranean cyclopoid species from several springs and wells in Korea, Ochridacyclops coreensis Chang and Itocyclops yezoensis (Ito). Recently, Lee and Chang (2007) described a new species of Acanthocyclops fonticulus from five mountain springs in South Korea.

Miura (1969) reported seven harpacticoid species including a new genus and three new species as a result of the speleological survey on 21 limestone caves and 49 wells of South Korea in spring of 1966 . However, any comprehensive taxonomic study on the cyclopoid copepods from caves has not been accomplished yet.

The authors have gathered cyclopoid specimens from more than 20 caves in South Korea since 1996. As a provisional result of examining the specimens, we identified 18 species of nine genera from 10 limestone caves, including four species new to Korean fauna. This paper deals with the taxonomic accounts of the four species, and the redescription of $A$. orientalis which has never been described and only briefly discussed in Russian.

\footnotetext{
*To whom correspondence should be addressed

Tel: 82-53-850-6454, Fax: 82-53-850-6459

E-mail: cychang@daegu.ac.kr
}

\section{MATERIALS AND METHODS}

Materials were collected from 10 limestone caves (Fig. 1) in South Korea mostly by the second (WRK) and third author (YGC), except for Sohan-gul Cave and Simbok-gul Cave by Dr. H.S. Rho, since August, 1996. Samplings were made sieving the bottom debris submerged in the cavern lakes and small bogs in the caves, with a plankton net or a hand net of $64 \mu \mathrm{m}$ mesh. Copepod samples were fixed and stored in $4 \%$ buffered formalin. All the specimens were dissected, drawn, and measured in lactophenol on H-S slide (Shirayama et al., 1993), a recent variation of Cobb slide. Dissection is performed using two needles made from $0.25 \mathrm{~mm}$ diameter tungsten wire by electrolysis (Huys and Boxshall, 1991; Huys et al., 1996). Dissected specimens were observed under a differential interference contrast microscope (Olympus BX51) with Nomarski optics. Figures were prepared with the aid of a camera lucida.

Abbreviations used in the text and figure legend follow the conventional ones frequently used in the taxonomy of freshwater copepods: enp 1-3 or exp 1-3, the first to third endopodal or exopodal segments of each leg.

\section{SYSTEMATIC ACCOUNTS}

Family Cyclopidae Sars, 1913

Subfamily Cyclopinae Kiefer, 1927

${ } *$ Megacyclops magnus (Marsh, 1920) (Figs. 2, 3)

Cyclops magnus Marsh, 1920, p. 8, pl. 3, figs, 11, 12, 14,

1*덩치검몰벼룩 (신칭) 


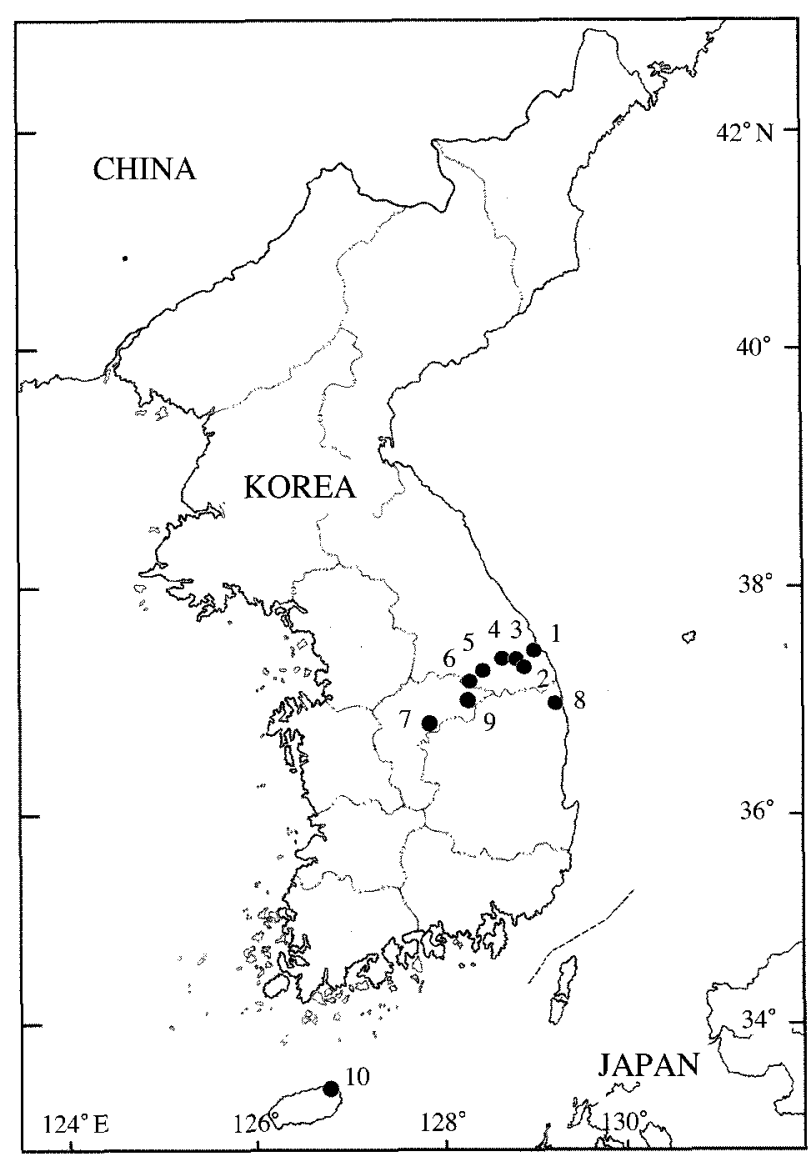

Fig. 1. Localities: 1, Sohan-gul Cave, Samcheok; 2, Hwanseon -gul Cave, Samcheok; 3, Daegeum-gul Cave, Samcheok; 4, Hwaam-gul Cave, Jeongseon; 5, Baekryong-gul Cave, Pyeongchang; 6, Bunjimi-gul Cave, Yeongwol; 7, Simbok-gul Cave, Goesan; 8, Seongryu-gul Cave, Uljin; 9, Ondal-gul Cave, Danyang; 10, Yongcheon-gul Lava tube, Jeju Is.

\section{pl. 4, figs. 1, 5 .}

Megacyclops magnus: Ishida, 2002, p. 54, fig. 23h-k.

Material examined. 3 우 우, 1 ㄱ, Baekryong-gul Cave, Pyeongchang, 14 Oct. 2005; 2 우우, Hwaam-gul Cave, Jeongseon, 12 Aug. 2005; 3 우 우, $1 \sigma^{7}$, Bunjimi-gul Cave, Yeongwol, 17 Jun. 2005.

Diagnosis. Female body (Fig. 2A) a little smaller than that of $M$. viridis, 0.9-1.1 mm long. Caudal rami about 4 times as long as wide. Inner (medial) margin hirsute, with irregularly arranged hairs (Fig. 2B, arrow); dorsal surface of rami rough. Lateral seta inserted at about posterior $1 / 4$ of lateral margin of ramus; proximal $1 / 4$ of lateral margin interrupted by minute spinules; outer caudal seta nearly $2 / 3$ times as long caudal ramus, and a little more than half the length of inner caudal seta; dorsal caudal seta nearly as long as outer caudal seta. Antennule (Fig. 2C) nearly reaching posterior margin of cephalothorax, consisting of 17 segments. Antennal basis ornamented with 7-8 slender spinules near middle of outer margin of frontal face (Fig. 2D); with 8-9 spinules along outer margin of caudal face (Fig. 2E); smooth in outer and inner distal corners of both faces. Legs 1-4 (Fig. 3A-D), both exopods and endopods 3-segmented; all couplers (intercoxal sclerites) of legs 1-4 each with 2 naked lateral lobes, without particular setule/spinule ornamentation on distal margin of caudal face. Spine formula (number of spines on exp 3 of legs 1-4) 2,3,3,3. Leg 4, coupler with 1 row of 12-17 spinules along middle of caudal face (Fig. 3D, arrow), both ends of spinule row pointing proximally; enp 3 about 2.2 times longer than wide, nearly as long as outer spine or slightly longer; outer spine 1.1-1.2 times longer than inner spine (Fig. 3D, arrow); plumose setae of enp 3 not transformed into spiniform setae, not exceeding end of outer spine. Leg 5 (Fig. 2F) composed of 2 free segments; proximal segment enlarged laterally, about 2 times longer than wide; distal segment with 1 minute spine medially and 1 long plumose seta apically.

Distribution. Korea, Japan (Hokkaido, northern part of Honshu), Russia (Kamchatka, Okhotsk).

Remarks. Prior to this report, only $M$. viridis (Jurine) has been known from South Korea in the genus Megacyclops Kiefer, 1927, which is a cosmopolitan species frequently and ubiquitously occurred from various habitiats including subterranean waters like wells and springs in South Korea. Megacyclops magnus differs from $M$. viridis by the characteristics as follows: outer spine on leg 4 enp 3 longer than inner spine (while inner spine longer in $M$. viridis); 14-18 spinules densely arranged in the middle of caudal face of coupler of leg 4 (while 6-8 slender spinules rather sparsely arranged in $M$. viridis); inner margin of caudal rami hirsute irregularly (against haired regularly and usually banded in 4 groups in $M$. viridis); the inner caudal seta a little (about 1.1 -1.2 times) longer than caudal ramus (while more than 1.5 times, and nearly 2 times longer in $M$. viridis).

Korean specimens coincide well with Japanese specimens except for a minor discrepancies of the spinule row in the coupler of leg 4 (the spinule row consisting of 16-18 spinules without gap in the middle of row, while about 12 spinules with a gap in Japanese specimens).

Megacyclops magnus is known as a boreal species, restricted to the Far East (Hokkaido, northern part of Honshu, Kamchatka, and Okhotsk) and Alaska, so this record from the caves at southern Gangwon-do Province is tentatively the southern limit of the geographical distribution of this species. 


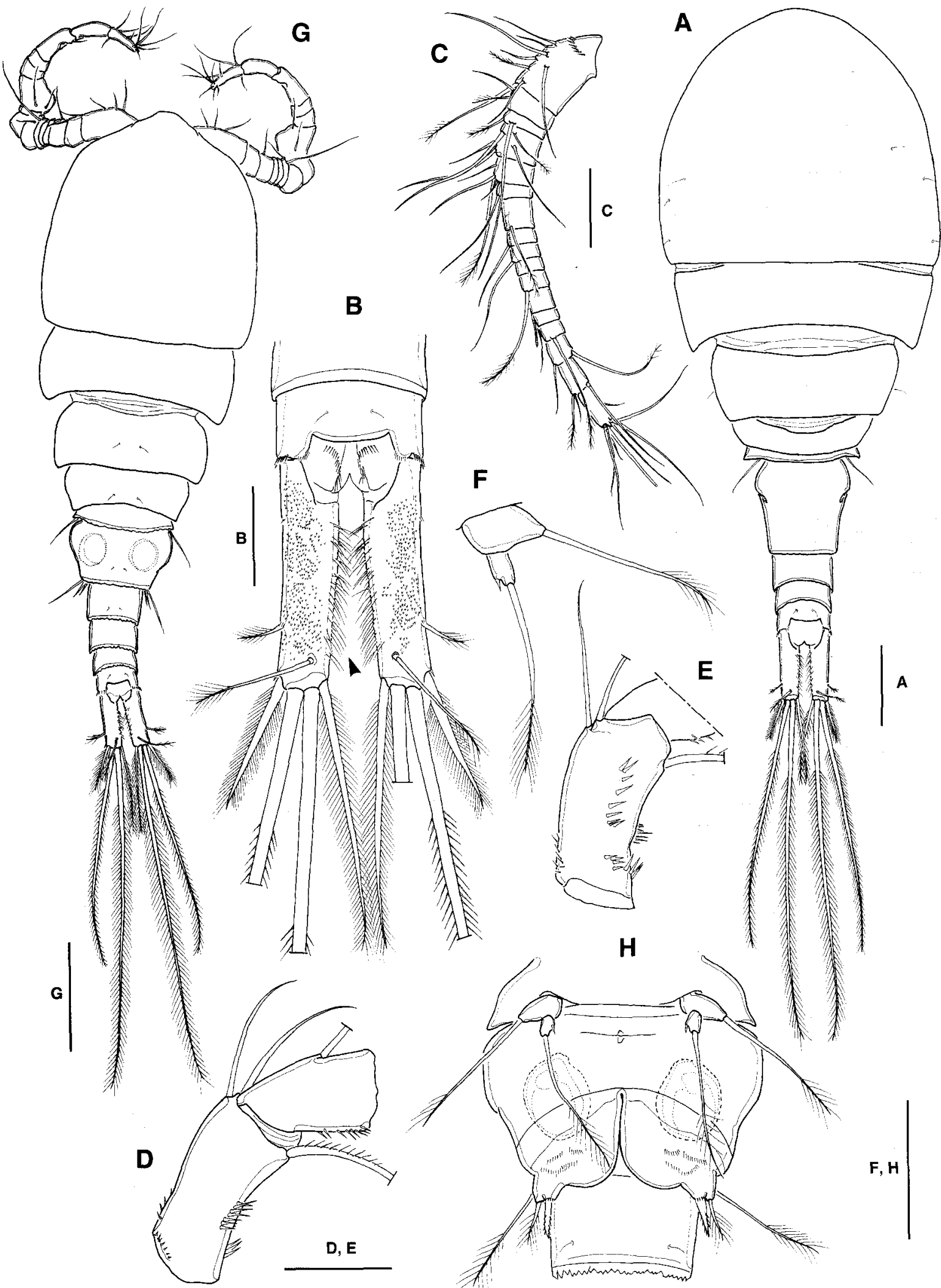

Fig. 2. Megacyclops magnus (Marsh). A-F, female: $A$, habitus, dorsal; $B, F u ; C, A 1 ; D, A 2$ basis, frontal; $E, A 2$ basis, caudal; $F$, P5. $G-H$, male: $G$, habitus, dorsal; $H, P 5$ and $P 6$. Scale bars $=0.2 \mathrm{~mm}(A, G), 0.1 \mathrm{~mm}(B-F, H)$. 

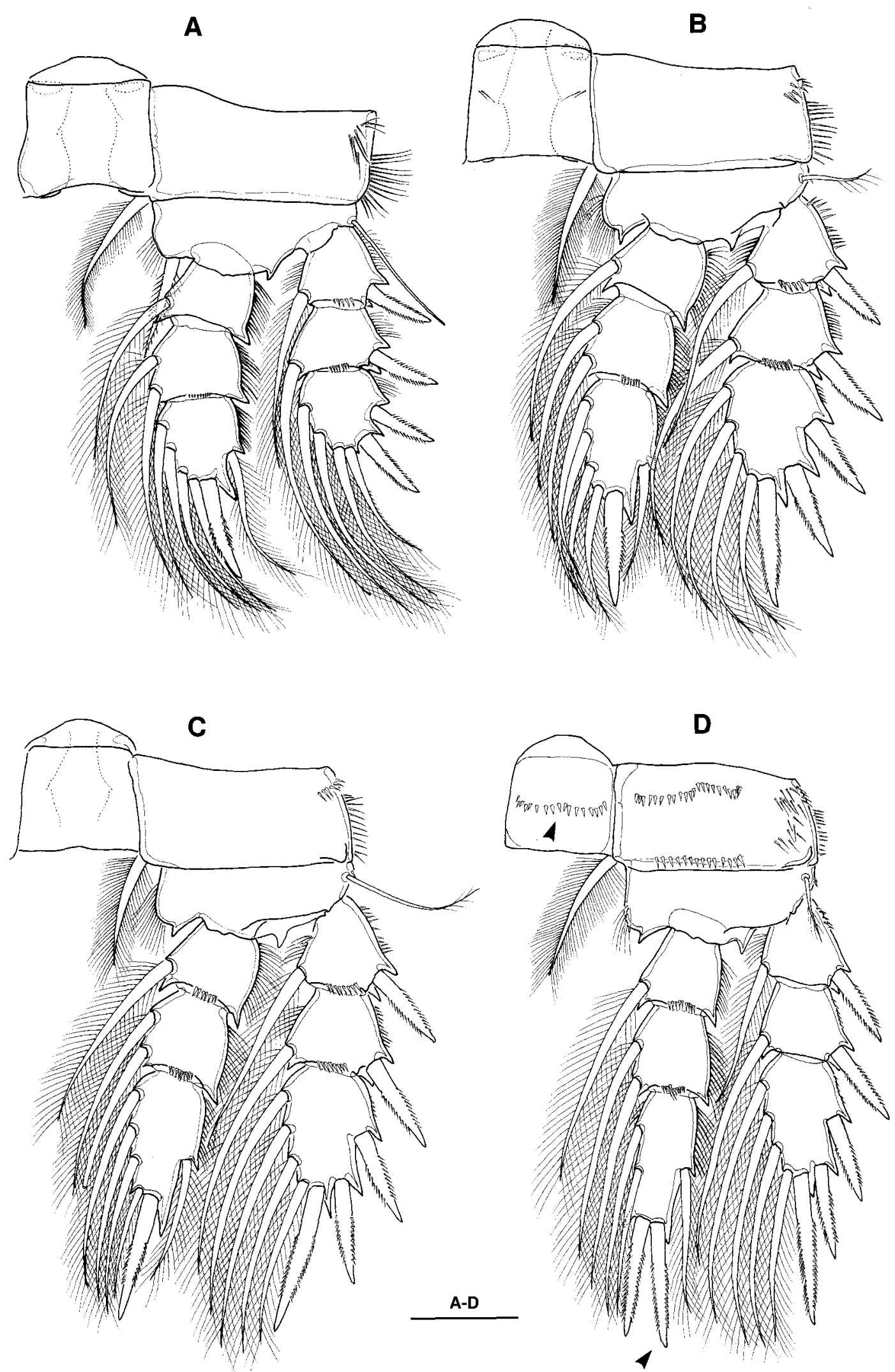

Fig. 3. Megacyclops magnus (Marsh), female. A-D, P1-P4. Scale bar=0.1 mm (A-D). 


\author{
${ }^{1}$ Acanthocyclops orientalis Borutzky, 1966 (Figs. 4, 5) \\ Acanthocyclops vernalis orientalis Borutzky, 1966, p. 772, \\ fig. 2. \\ Acanthocyclops orientalis: Dussart and Defaye, 1985, p. 80; \\ Reid et al., 1991, p. 145.
}

Material examined. 2 우 우, 1 万人, Hwaam-gul Cave (Cheonpo Spring), Jeongseon, 10 Nov. 2005; 1 우, Daegeum-gul Cave, Samcheok, 18 Feb. 2005; 4 우우, Baekryong-gul Cave, Pyeongchang, 6 Jun. 2006; 1 ð , Seongryu-gul Cave, Uljin, 17 Feb. 2005; 1 우, same locality, 9 Jun. 2005; 2 우우, Ondal -gul Cave, Danyang, 13 Aug. 2007 (J.M. Lee, W.-R. Kim and Y.-G. Choi).

Female. Body (Fig. 4A) big, about $0.9 \mathrm{~mm}$ long excluding caudal seta. Tinged with milky gray. Prosome oval, 1.1 times longer than urosome. Rostrum reduced. Cephalothorax somewhat protruding anteriorly, about 1.5 times longer than next three thoracic somites combined. Nauplius eye not observed. Genital somite 1.2 times longer than wide, anterior half rather swollen laterally. Pedigers 4 and 5 rather protruding posterolaterally. Posterior margins of all urosomites with hyaline fringes weakly crenulated; posterior margin of anal somite with 15-20 fine spinules ventrally. Anal operculum not strongly convex, smooth on its posterior margin.

Caudal rami about 4.0-5.5 times as long as wide, without hairs along inner (medial) margin (Fig. 4B). Lateral margin smooth without interruption at proximal quarter; lateral seta inserted at about posterior quarter of lateral margin of ramus. Outer caudal seta about $1 / 2$ times as long as caudal ramus, and a little less than 2/3 times the length of inner caudal seta. Dorsal caudal seta a little shorter than inner caudal seta, and about $3 / 4$ times as long as caudal ramus.

Antennule (Fig. 4C) 17-segmented, slightly not reaching posterior margin of cephalothorax; 12 th segment bearing 1 aesthetasc on lateral margin, its tip much beyond posterior margin of 14th segment.

Antenna (Fig. 4D, E), both frontal and caudal face of basis smooth distally; caudal face of basis ornamented with 5 long setules near middle of outer margin.

Legs 1-4 (Fig. 5A-D), all exopods and endopods 3-segmented. Spine formula (number of spines on $\exp 3$ of legs 1-4) $2,3,3,3$. Seta formula (number of setae on exp 3 of legs 1-4) 4,4,4,4. Spine/seta armature of legs 1-4 as follows (Arabic numerals representing setae, while Roman numerals indicating spines):

Leg 1 coxa $0-1$ basis $1-1 \operatorname{exp~I-1;~I-1;~II,1,3~}$ enp $0-1 ; 0-2 ; 1,1,3$

Leg 2 coxa 0-1 basis 1-0 exp I-1; I-1; II,I,4 enp $0-1 ; 0-2 ; 1, \mathrm{I}+1,3$
Leg 3 coxa 0-1 basis 1-0 exp I-1; I-1; II,I,4 enp $0-1 ; 0-2 ; 1, I+1,3$

Leg 4 coxa $0-1$ basis $1-0 \operatorname{exp~I-1;~I-1;~II,I,4~}$ enp $0-1 ; 0-2 ; 1, \mathrm{II}, 2$

Couplers of legs $1-3$ each with 2 lateral lobes, each ornamented with 1 curved row of hairs distally and medially. Distomedial corner of basis of leg 1 with 1 long seta, exceeding enp 2. Leg 4, lateral lobes of coupler not producing; posterior margin smooth; 19-20 slender spinules densely arranged in 1 row in the middle of caudal face (Fig. 5D, arrow), both lateral ends curved proximally; spinule row present along posterior margin of coxa, with a gap between two groups of spinules with different sizes and shapes (Fig. 5D, arrow); enp 3 about 2.5-3.0 times as long as wide; inner apical spine about 1.2 times as long as outer apical spine, about $3 / 4$ times as long as enp 3; setae of enp 3 not transformed into spiniform seta; inner setae much beyond tip of inner spine, while outer seta nearly reaching or slightly beyond it (Fig. 5D).

Leg 5 (Fig. 4F) composed of 2 free segments; first segment a little enlarged laterally, about 1.5 times wider than long, with 1 seta distolaterally. Distal segment about 2 times longer than wide, with 1 inner spine and 1 long plumose apical seta; inner spine rather short (less than half the distal segment). Leg 6 represented by 2 strong conical projections and 1 long plumose seta, locating at both sides of dorsoanterior part of genital somite.

Male. Leg 5, distal segment about 1.5 times as long as wide, inner margin rounded, inner spine very short, locating distolaterally. Leg 6 represented by indistinctly separated plate with innermost spine, middle seta (nearly as long as inner spine), and outer (subdorsal) seta (about 2 times longer than inner spine).

Distribution. Korea, Russia (the Maritime Territory).

Remarks. Acanthocyclops orientalis was described from a cave in the Maritime Territory of Russia by Borutzky (1966), as a subspecies of A. vernalis. In spite of his insufficient and inadequate figures and brief discussion in Russian without description, A. orientalis is enough to be recognized as a valid species distinguished from $A$. vernalis as Petkovski (1975) mentioned, and identified with Korean specimens in having the longer inner spine on leg 4 enp 3 (while usually outer spine longer in A. vernalis) and the elongate setae on leg 4 enp 3 (much exceeding the spines on enp 3 in A. orientalis, while usually not reaching the tip of outer spine in A. vernalis). Moreover, based upon Korean specimens, $A$. orientalis shows some discrepancies consistently from $A$. vernalis as follows: (1) small body $(0.8-0.9 \mathrm{~mm})$, while usually much more than $1 \mathrm{~mm}$ in A. vernalis; (2) posterolateral

$1 *$ 동방가시검물벼쿡 (신칭) 


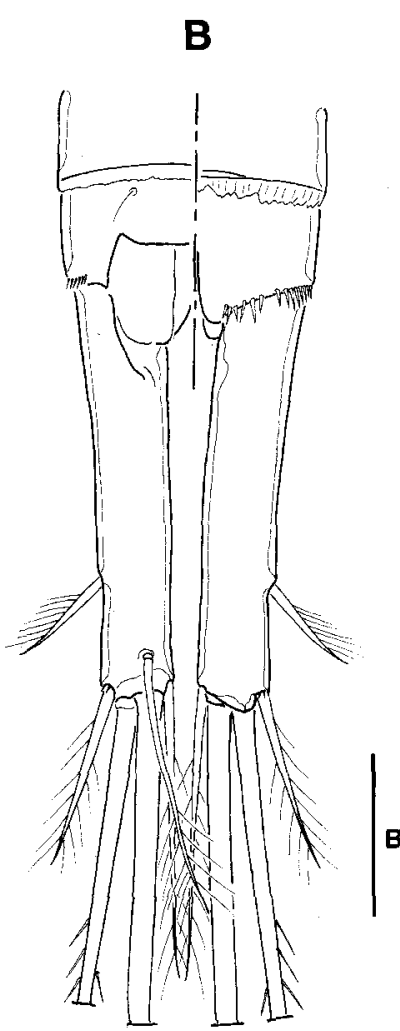

A
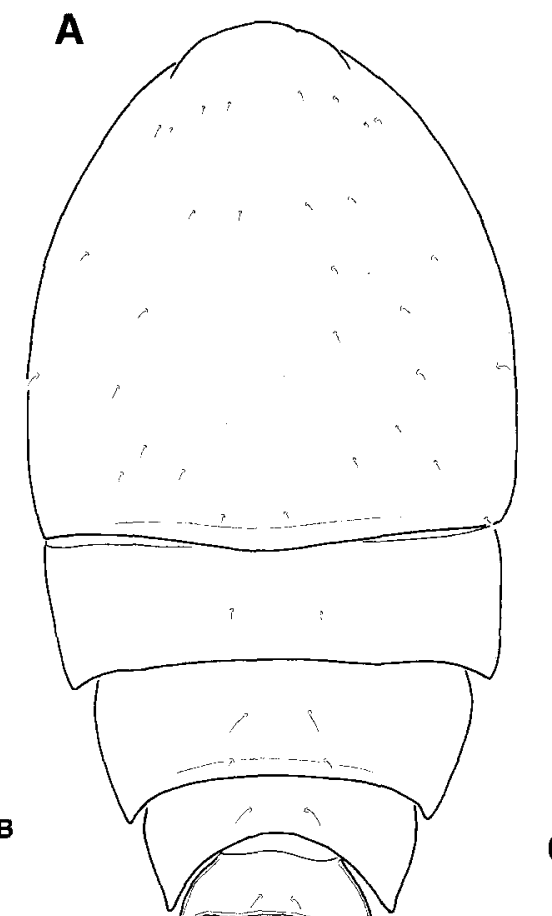

C
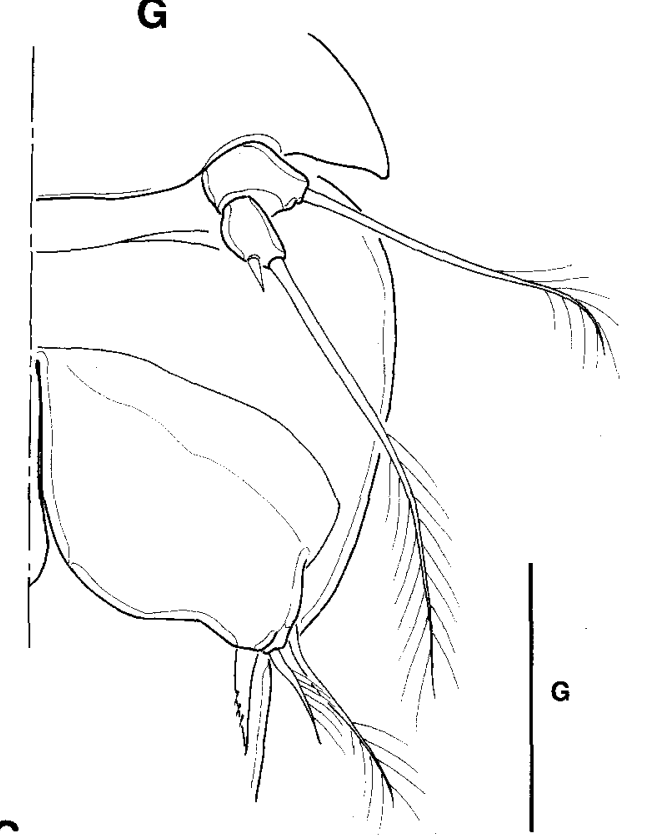

G

将
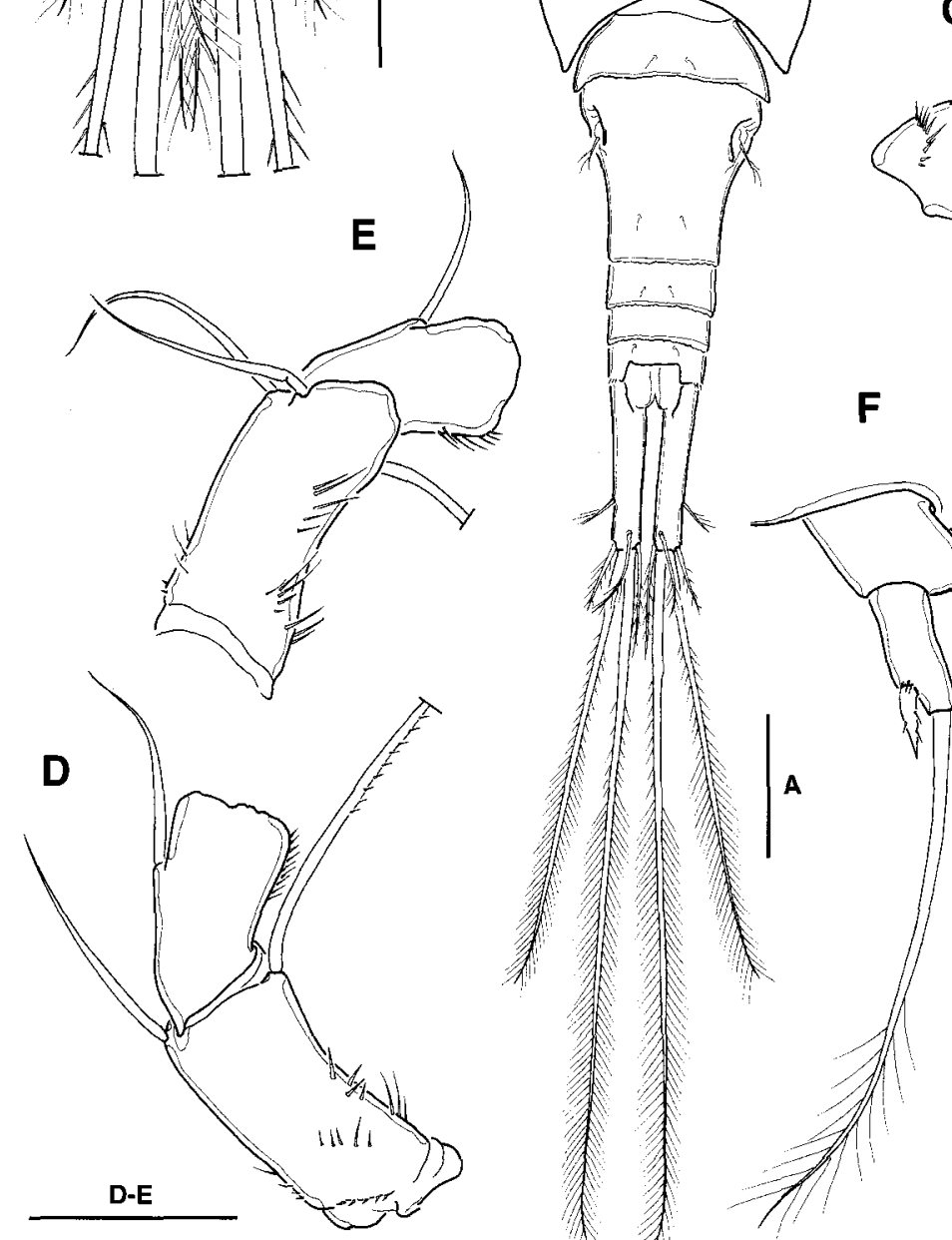

$x_{3}$

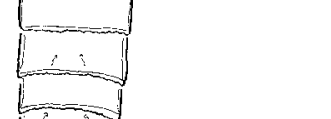

$+1$
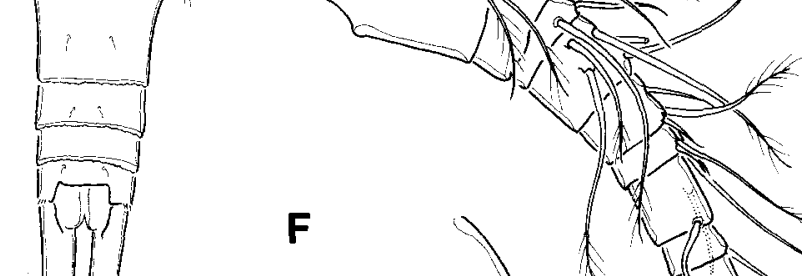

$\mathbf{F}$
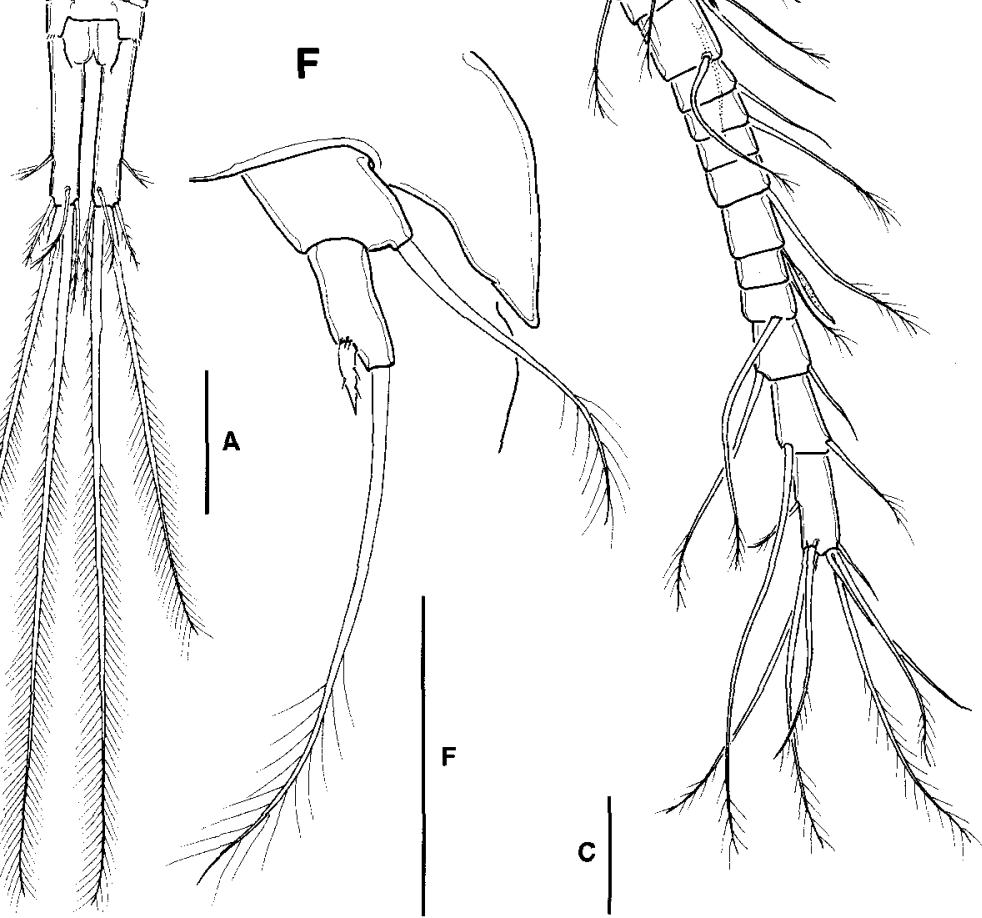

Fig. 4. Acanthocyclops orientalis Borutzky. $A-F$, female: $A$, habitus, dorsal; $B, F u$;,$A 1$; $D, A 2$ basis, frontal; $E$, $A 2$ basis, caudal; $F$, P5. G, male P5 and P6. Scale bars $=0.1 \mathrm{~mm}(A), 0.05 \mathrm{~mm}(B-G)$. 

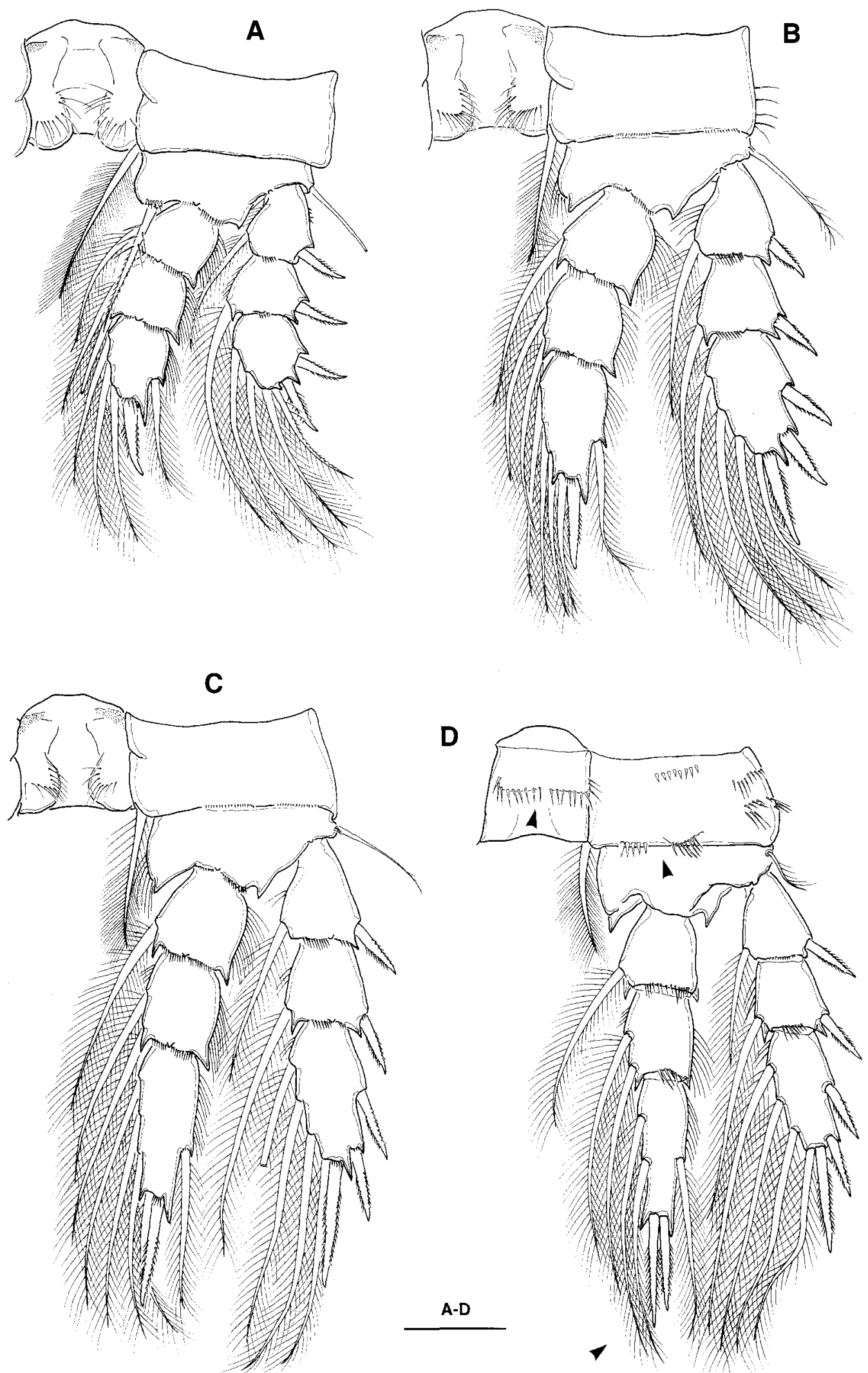

Fig. 5. Acanthocyclops orientalis Borutzky, female. A-C, P1-P3, frontal; D, P4, caudal. Scale bar=0.05 mm (A-D). 
edges of pedigers 4 and 5 not strongly protruded; (3) the lateral margin of caudal rami without interruption at proximal quarter; (4) a row of 18-19 spinules on the caudal face of coupler of leg 4 densely arranged and not interrupted in the middle of spinule row (cf. Fig. 5D), while 8-9 spinules sparsely arranged, sometimes with some gap in the middle of the row in A. vernalis; (5) spinule row along posterior margin of coxa shows a gap between two groups of spinules with different sizes and shapes (cf. Fig. 5D), while the spinule row consisting of similar spinules without gap in the middle in A. vernalis; (6) dorsal caudal seta about 1.5 times longer than outer caudal seta (while nearly same in length or less than 1.2 times longer in A. vernalis). 'Acanthocyclops cf. orientalis' sensu Petkovski (1975) from Jugoslavia is different from the Borutzky's figure as well as Korean specimens by shorter dorsal caudal seta than outer caudal seta and the presence of interruption on the lateral margin of caudal rami. As he did not present the coupler and coxa of leg 5, we cannot confirm the spinule arrangement, which shows the high consistency among Korean specimens.

Korean specimens occurred from five limestone caves, and show the characteristics above rather consistently. In the Hwaam-gul Cave, Jeongseon, this species co-occurred with $A$. vernalis, where two species showed the character displacement, that is, emphasizing their morphological discrepancies for sexual isolation between the two species. This species frequently co-occurs with Atheyella coreana Miura, 1969.

\footnotetext{
${ }^{1 * \text { Acanthocyclops robustus (Sars, 1863) (Fig. 6) }}$

Cyclops robustus Sars, 1863, p. 245.

Acanthocyclops robustus: Kiefer, 1929, p. 55; Petkovski,

1975, p. 107, figs. 21-41; Reid et al., 1991, p. 145; Ishida,

2002 , p. 55 , fig. 24 j-n.

Cyclops vernalis var. robustus: Gurney, 1933. p. 201, fig. 1612.
}

Acanthocyclops vernalis var. robustus: Rylov, 1948, p. 226, fig. 47.

Acanthocyclops (Acanthocyclops) robustus: Dussart, 1969, p. 126 , fig. 56 .

Material examined. 2 우 우, Sohan-gul Cave, Samcheok, 12 May 1994(H.S. Rho).

Diagnosis. Body big, 1.1-1.3 mm in female. Pedigers 4 and 5 protruding posterolaterally. Anterior part of genital somite swollen laterally. Seminal receptacle lip-shaped, both upper and lower parts narrow. Caudal rami (Fig. 6B) 4.0-4.5 times as long as wide, with 4-6 bands of minute spinules on both dorsal and ventral surfaces; inner (medial) margin smooth; lateral seta inserted at about posterior $1 / 4$ of lateral margin of ramus; outer caudal seta a little less than 3/4 times as long as inner caudal seta; dorsal caudal seta a little longer than outer caudal seta, but shorter than inner caudal seta; outer terminal caudal seta stout, pinnate with spinules along distal $2 / 3$ of seta (Fig. 6A, B, arrow). Antennule 17-segmented, not reaching posterior margin of cephalothorax. Antennal basis smooth at distal part of both frontal and caudal faces, with 7-8 spinules along middle of outer margin of caudal face (Fig. 6D, E). Legs 1-4, both exopods and endopods 3 segmented; spine formula 3,4,4,4. Leg 4 (Fig. 6F), enp 3 about 2.3 times as long as wide, about 1.5 times longer than outer spine; outer spine slightly (1.1 times) longer than inner spine; outer seta modified into spiniform, nearly as long as outer spine; inner setae also transformed into spiniform setae, not reaching tip of spines; exp 3 with 4 inner setae, distal three of which modified into spiniform. Leg 5 (Fig. $6 C$ ), proximal segment a little enlarged laterally, about 1.5 times wider than long; distal segment about 1.5-2 times longer than wide, with 1 short inner distal spine and 1 long apical seta. Leg 6 represented by 3 conical projections on wrinkled genital operculum, dorsally locating at both sides of anterior part of genital somite (Fig. 6A).

Distribution. Holarctic (Korea, Japan, Russia, Europe, North America).

Remarks. Acanthocyclops robustus is closely allied with $A$. vernalis and $A$. orientalis. This species resembles $A$. vernalis in the general appearances (especially the produced distolateral margins of pedigers 4 and 5), the shape of caudal rami with the relative length ratios among caudal setae, the shape of leg 4 enp 3 and the relative length between its two apical spines, and the spinulation on basis of antennal exopod. However, A. robustus differs from $A$. vernalis by the transformed spiniform setae on leg 4 enp 3 and $\exp 3$, the pinnate outer terminal caudal seta, the spine formula (usually $3,4,4,4$ in A. robustus, against 2,3,3,3 in A. vernalis), and anterior part of genital somite with rounded lateral margin.

\section{${ }^{2} *$ Diacyclops suoensis (Ito, 1954) (Figs. 7, 8)}

Diacyclops languidoides suoensis Ito, 1954, p. 399, figs. 144-148.

Diacyclops suoensis: Mizuno, 1984, p. 597, fig. 338; Ueda et al., 1996, p. 309, fig. 4.

Material examined. 1 오, Ondal-gul Cave, Danyang, 13 Aug. 2007 (J.M. Lee, Y.-G. Choi and W.-R. Kim); 1 우, Yongcheon-gul Lava tube (cavern lake), Jeju Is., 16 Jul. 2005 (Y.-G. Choi and W.-R. Kim).

${ }^{1 *}$ 튼튼가시검물벼룩(신칭), ${ }^{2 *}$ 나비맵시검물벼룩 (신칭) 


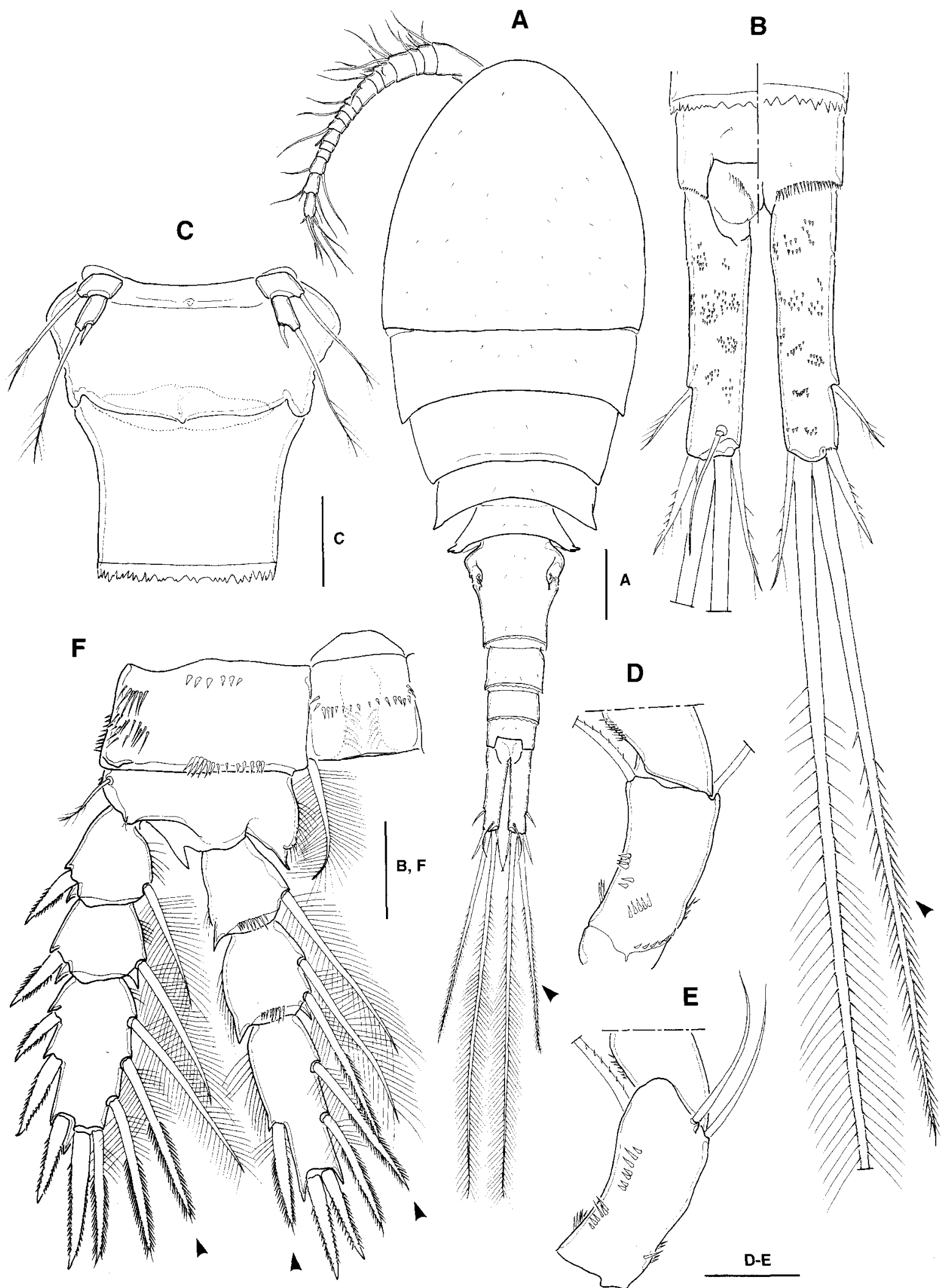

Fig. 6. Acanthocyclops robustus (Sars), female. A, habitus, dorsal; B, Fu; C, P5 and genital segment; D, A2 basis, frontal; E, A2 basis, caudal; F, P4. Scale bars $=0.1 \mathrm{~mm}(A), 0.05 \mathrm{~mm}(B-F)$. 


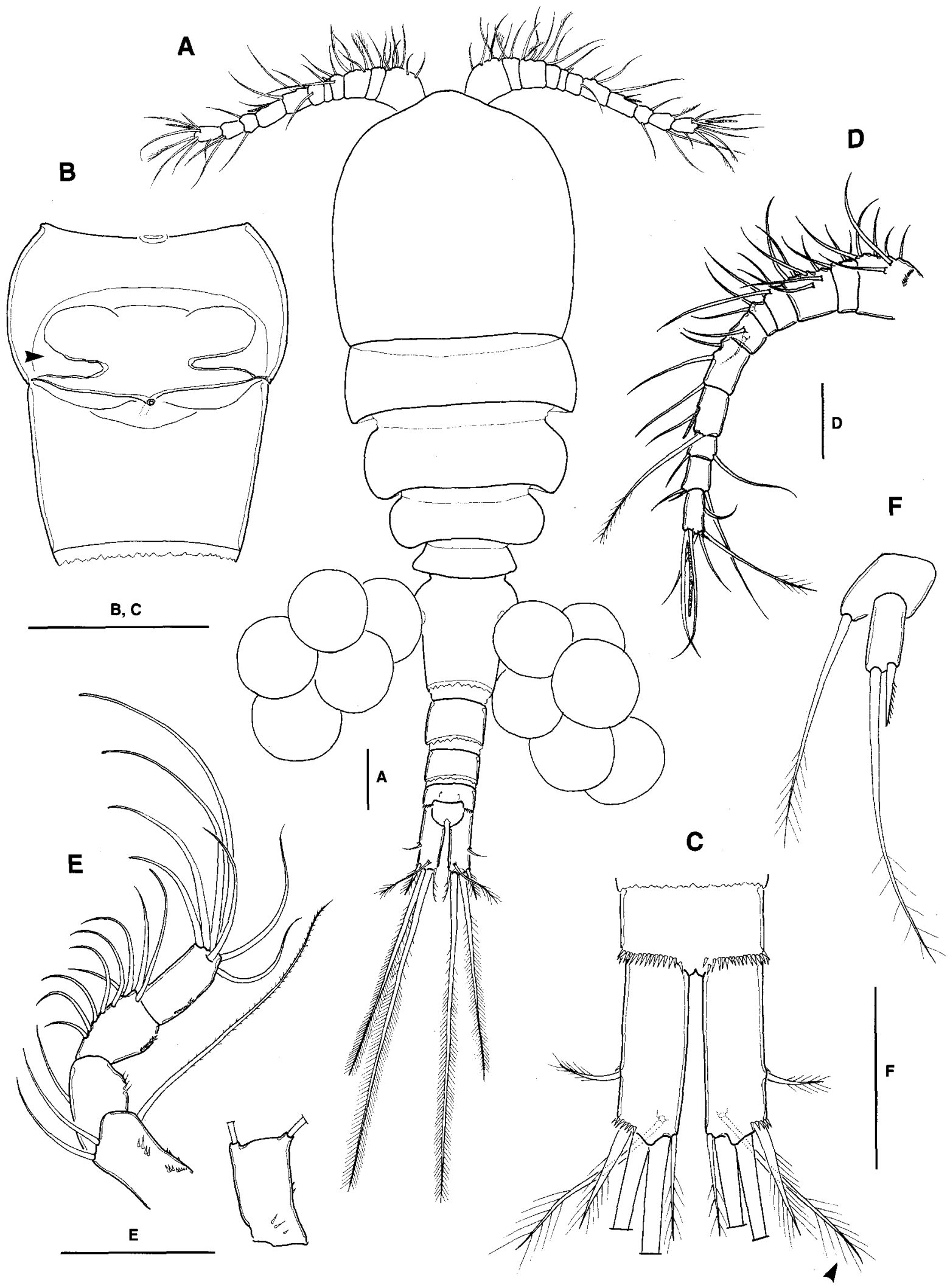

Fig. 7. Diacyclops suoensis (Ito), female. A, habitus, dorsal; B, genital somite, ventral; C, Fu and anal somite, ventral; D, A1; E, $A 2$, caudal, with basis, frontal; F, P5. Scale bars $=0.05 \mathrm{~mm}(A-E), 0.02 \mathrm{~mm}(F)$. 

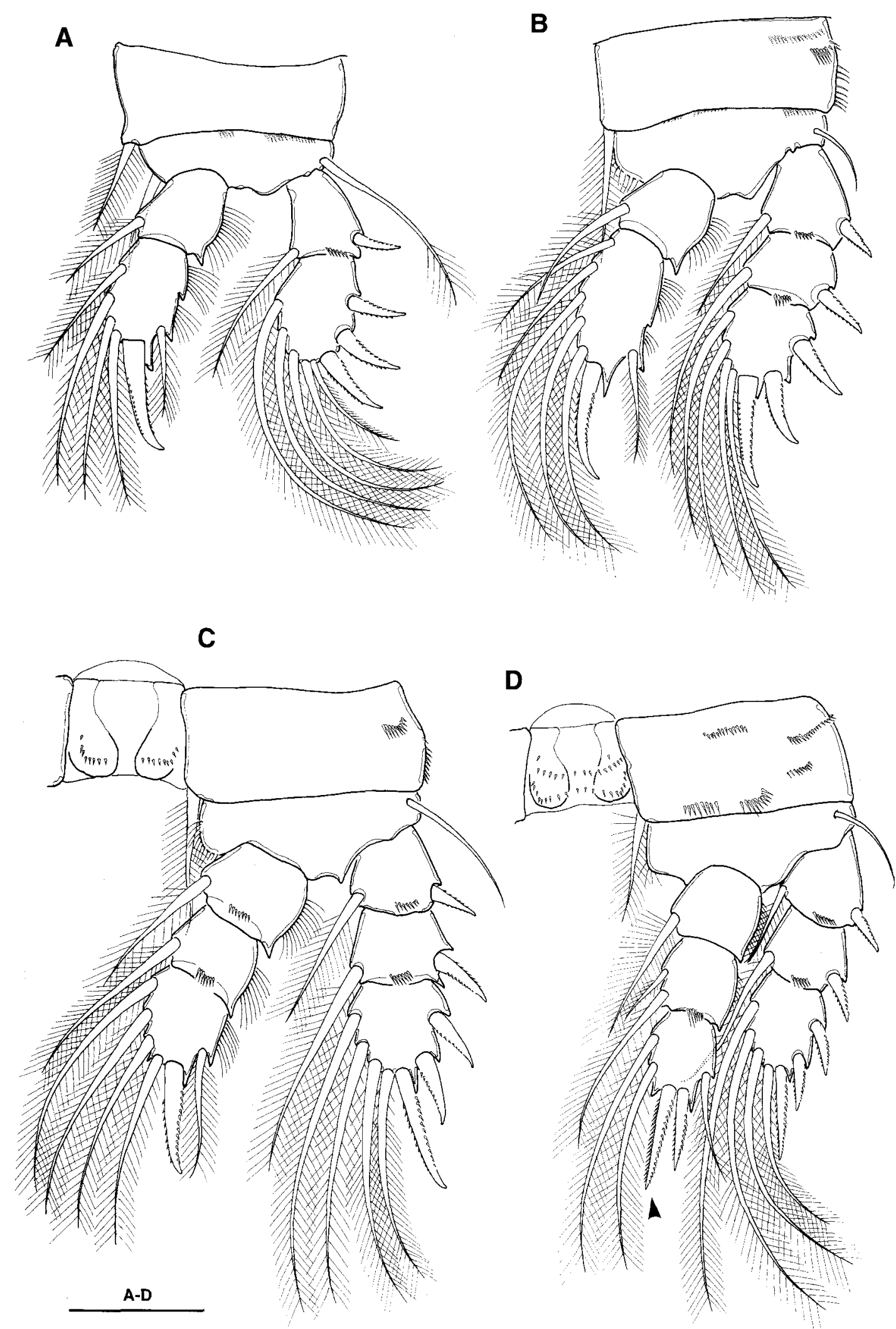

Fig. 8. Diacyclops suoensis (Ito), female. A-D, P1-P4, caudal. Scale bar $=0.05 \mathrm{~mm}$ (A-D). 
Diagnosis. Body small and a little slender, 0.6-0.7 mm long in female. Seminal receptacle butterfly-shaped, both sides of anterior half deeply concaved (Fig. 7B). Anal operculum not strongly convex, smooth on its posterior margin. Caudal rami 3.0-3.6 times as long as wide, without hairs along inner (medial) margin (Fig. 7C); lateral seta inserted at about posterior $1 / 3$ of lateral margin of ramus; outer caudal seta slightly less than $2 / 3$ times as long as caudal ramus, a little longer than inner caudal seta; dorsal caudal seta long, nearly 2 times longer than inner caudal seta. Antennule (Fig. 7D) 11-segmented, slightly exceeding posterior margin of cephalothorax; 8th and last segments each bearing 1 asthetasc. Antenna (Fig. 7E), caudal face of basis ornamented with 4-5 spinules near middle of outer margin. Legs 1-4 (Fig. 8A-D), segmentation of exopod/endopod 2/2, 3/2, 3/3, $3 / 3$. Spine formula $3,3,3,3$. Leg 4 , lateral lobes of coupler not producing, with smooth posterior margin; caudal face of coupler armed with 2 spinule rows, each consisting of about 16 spinules in the middle and 20 at posterior part, respectively; enp 3 about 1.2 times as long as wide, about $3 / 4$ times as long as inner spine; inner spine about 1.4 times longer than outer spine; inner setae much beyond inner seta, while outer seta slightly not reaching (Fig. 8D). Leg 5 (Fig. $7 \mathrm{~F}$ ) composed of 2 free segments; first segment a little enlarged distolaterally, about 1.5 times wider than long; distal segment about 2 times longer than wide, with 1 distomedial spine and 1 long plumose apical seta. Leg 6 represented by 2 strong conical projections and 1 long plumose seta, locating at both sides of dorso-anterior part of genital somite. Ovigerous females generally bearing 5-6 eggs in each egg sac.

Remarks. This species was described from wells situated at southwestern coasts of Honshu, Japan by Ito (1954) as a new subspecies of Diacyclops languidoides (Lilljeborg, 1901). He proposed two characteristics as the decisive characters, the butterfly-shaped seminal receptacle (cf. Fig. 7B) and the elongate dorsal caudal seta, which was more than 3 times as long as outer caudal seta. However, in Korean specimens examined, the dorsal caudal seta is not so long as in the original description, ranging from 1.6 to 2.1 times (mean 1.9 , in a total of 13 specimens examined, including the specimens collected from wells in South Korea). The length to width ratio of caudal rami, and that of leg 4 enp 3 are somewhat variable, as in $D$. languidoides.

This species has been known as a subterranean species. In South Korea, this species was also found in several wells or springs, especially situated not far from sea shore (unpublished data).

Distribution. Korea, Japan.

\section{ACKNOWLEDGEMENTS}

Last author (CYC) thanks Dr. Hyun Soo Rho (Korea Ocean Research and Development Institute) for collecting samples at Simbok-gul Cave and Sohan-gul Cave. He is grateful to the late Dr. Teruo Ishida and Dr. Janet Reid for providing references. This work was financially supported to Cheon Young Chang by the Eco-Technopia 21 Project, the Ministry of Environment, Korea, and to Yong-Gun Choi and Won-Rok Kim by Cave Research Institute of Korea.

\section{REFERENCES}

Borutzky, E.V., 1966. Copepoda of the caves of the marine territory (Primorski Kral). Zool. Zh., 45(5): 770-772. (Russian with English summary).

Dussart, B., 1969. Les Copépodes des eaux continentales d'Europe occidentale. Tome II: Cyclopoïdes et Biologie. N. Boubée et Cie, Paris, pp. 1-292.

Dussart, B. and D. Defaye, 1985. Répertoire mondial des copépodes cyclopoïdes. Ed. C.N.R.S., pp. 1-236.

Gurney, R., 1933. The British fresh-water Copepoda. Vol. 3, Cyclopoida, Caligoida. Ray Society, London, pp. 1-334.

Huys, R. and G.A. Boxshall, 1991. Copepod evolution. The Ray Society, London, pp. 1-468.

Huys, R., J.M. Gee, C.G. Moore and R. Hamond, 1996. Marine and brackish water harpacticoid copepods. Part I. Synopses of the British fauna (New Series), 51: 1-352.

Ishida, T., 2002. Illustrated fauna of the freshwater cyclopoid copepods of Japan. Bull. Biogeogr. Soc. Japan, 575: $37-$ 106. (in Japanese)

Ito, T., 1954. Cyclopoid copepods of Japanese subterranean waters. Rep. Fac. Fish., Pref. Mie Univ., 1(3): 372-417.

Kiefer, F., 1929. Crustacea Copepoda. II. Cyclopoda Gnathostoma. Das Tierreich, Berlin and Leipzip, 53: 1-102.

Kim, H.S. and C.Y. Chang, 1991. Acanthocyclops tokchokensis, a new cyclopoid copepod species from wells in Tokchok Island of Korea. Korean J. Zool., 34: 300-306.

Lee, J.M. and C.Y. Chang, 2007. Acanthocyclops fonticulus (Cyclopoida, Cyclopidae), a new species of cyclopoid copepods from mountain springs in Korea. Integr. Biosc., 11(1): 61-68.

Lee, J.M., J.M. Jeon and C.Y. Chang, 2004. Two semi-subterranean Copepods from Korea. Korean J. Biol. Sci., 8: 145154.

Marsh, C.D., 1920. Freshwater Copepoda. Report of the Canadian Arctic Expedition 1913-1918, 7(J): 1-25.

Miura, Y., 1969. Results of the speleological survey in South Korea 1966 XIV. Subterranean harpacticoid copepods of South Korea. Bull. Nat. Sci. Mus. Tokyo, 12: 241-254.

Mizuno, T., 1984. Nihon-no Rikusuisan Cyclopoida. In Shen, C.J. and T. Mizuno, eds, Chinese/Japanese Freshwater 
Copepoda. Tatara-shobo, Yonago, pp. 564-620.

Petkovski, T.K., 1975. Revision von Acanthocyclops-formen der vernalis-groups aus Jugoslawien (Crustacea, Copepoda). Acta Mus. Maced. Sci. Nat, Skopje, 14(5): 93-142.

Reid, J.W., E.B. Reed, J.V. Ward, N.J. Voelz and J.A. Stanford, 1991. Diacyclops languidoides (Lilljeborg, 1901) s.l. and Acanthocyclops montana, new speceids (Copepoda, Cyclopoida), from groundwater in Montana, USA. Hydrobiologia, 218: 133-149.

Rylov, V.M., 1948. Freshwater Cyclopoida. Fauna of U.S.S.R., Crustacea. Israel Program for Scientific Translations, Jerusalem, 3(3): 1-318.
Sars, G.O., 1863. Oversight af de indenlandske Ferkvandscopepoder. Forhd1. Vidensk. Selskab. Christiania, (Jahr. 1862): 212-262.

Shirayama, Y., T. Kaku and R.P. Higgins, 1993. Double-sided microscopic observation of meiofauna using an HS-slide. Benthos Res., 44: 41-44.

Ueda, H., S. Ohtsuka and T. Kuramoto, 1996. Cyclopoid copepods from a stream in the limestone cave Akiyoshido. Japan. J. Zool., 57(4): 305-312.

Received September 19, 2007 Accepted October 26, 2007 